Hervin Fernández-Aceves

Postdoctoral Research Associate, Lancaster University

hervin.fernandez@lancaster.ac.uk

\title{
Power and society in medieval Sardinia
}

As a Rome Awardee, I carried out research for what I intended to be a new post-doctoral project on medieval Sardinia and upon the understanding and representation of its society and political autonomy. To this day, little is known of the island's socio-political dynamics during the central Middle Ages (late tenth to twelfth centuries AD), and a reconsideration not only of its local sources but also of the different modern historiographical traditions is a fundamental step to take. The British School at Rome Library and the extended URBiS library network, together with the Italian language course and the opportunity to meet other fellows and scholars who passed through the BSR, were instrumental in developing this first phase of historiographical interpretation. In particular, my three months at the BSR were spent understanding both the full background of and the historiography around the Sardinian diplomatic sources. I completed a survey and critique of the works of Alberto Boscolo, Enrico Besta and Francesco Cesare Casula, key historians who shaped most of the historiography of medieval Sardinia in the twentieth century. At the BSR I was able to consult the foundational work of Giovanni Francesco Fara, De rebus Sardois liber, a sixteenth century historical and geographical treatise that became the main reference framework and source for subsequent, modern historiographical traditions. Additionally, I invested some time re-evaluating the impact that French structuralism and the notions of 'feudalism' had on contemporary Sardinian historiography, by reconsidering, for example, the works of Marc Bloch, Fernand Braudel and Guy Bois, in the light of new research questions and the available Sardinian sources. In terms of source work, I consulted and examined the edition of the condaghe of Barisone of Torres, a key primary source for my study that is accessible only in the publication Mondo rurale e Sardegna del XII secolo. Beyond the BSR's Library, I was granted access to the repositories of the École Française and the Bibliotheca Hertziana. In the former, I was able to consult additional key collective volumes, recently published monographs and edited sources. Access to the Hertziana, on the other hand, allowed me to improve my survey of primary sources, as there I was able to work on the extensive Genealogie medioevali di Sardegna and an edited primary source, Il condaghe di San Gavino. An examination of the many recent works by Giovanni Serreli and Alessandro Soddu - contemporary scholars who have worked extensively on similar research questions to mine - was another of the significant activities that I was able to conduct using monographs, collective volumes and journals available in both the BSR and the École Française. I also had the opportunity to work on the revision of my doctoral thesis, which will be published in book form as County and Nobility in Norman Italy (London, I.B. Tauris).

At the end of my Award, I produced a draft of two papers examining the context and use of the Sardinian condaghes, to be presented at the Sixth Biennial Conference of the Society for the Medieval Mediterranean and the International Medieval Congress respectively. I hope to synthesize these first results in a paper for the Papers of the British School at Rome this year. Overall, my experience at the BSR strengthened my 
post-doctoral background and helped in the success of my application to the collaborative AHRC-funded project 'Power, society and (dis)connectivity in medieval Sardinia'. Under this project, I have been able to continue my own research, employed as a Research Associate, on the social and political relations between the rulers, the rural élites, small landholders and the wider population of Sardinia during the central Middle Ages. I thank all the staff at the BSR and my artistic and academic colleagues for their help; their company was a constant source of support and inspiration. 